\title{
Upaya Peningkatan Daya Saing Usaha Mikro, Kecil, dan Menengah (UMKM) Kota Tasikmalaya melalui Pemanfaatan System Informasi Geografis (SIG)
}

\author{
Syti Sarah Maesaroh \\ Program Studi Bisnis Digital, Universitas Pendidikan Indonesia Kampus Tasikmalaya \\ Jl. Dadaha No.mor 18, Kahuripan, Kec. Tawang, Tasikmalaya, Jawa Barat 46115 \\ Email: sytisarah@upi.edu
}

\begin{abstract}
.
The development of the creative economy in Indonesia is appropriate through the Micro, Small and Medium Enterprises (MSMEs) model. One of the potential cities for the development of MSMEs is Tasikmalaya City. However, the competitiveness of MSMEs in Tasikmalaya City is still considered low. The determinat variables that observed in this study are human resources, technology, managerial, institutional, promotion, and capital. The aim of the study is to analyze the competitiveness of MSMEs in Tasikmalaya City as an effort in developing the regional economy. This research uses quantitative descriptive method. Data was collected through an interview process using a questionnaire. Data is processed using Geographic Information System (GIS). The results showed that human resources were the most important factor in increasing MSMEs competitiveness (42\%). In addition to improving skills in human resources, revitalization in managerial systems and easy access to technology in MSMEs are also needed.
\end{abstract}

Keywords: Competitiveness; Geographic Information System; MSMEs

Abstrak.

Pengembangan ekonomi kreatif di Indonesia sangat tepat dilakukan melalui model Usaha Mikro, Kecil dan Menengah (UMKM). Salah satu kota yang potensial untuk pengembangan UMKM yaitu kota Tasikmalaya. Namun, daya saing UMKM di Kota Tasikmalaya dinilai masih rendah. Variabel penentu daya saing dalam penelitian ini adalah sumber daya manusia, teknologi, manajerial, kelembagaan, promosi, dan modal. Tujuan dari penelitian ini adalah untuk menganalisis daya saing UMKM di Kota Tasikmalaya sebagai upaya mengembangkan ekonomi daerah. Penelitian ini menggunakan metode deskriptif kuantitatif. Data dikumpulkan melalui proses wawancara menggunakan kuesioner. Pengolahan data dilakukan dengan menggunakan Sistem Informasi Geografis (SIG). Hasil penelitian menunjukkan bahwa sumber daya manusia adalah faktor yang paling penting dalam meningkatkan daya saing UMKM (42\%). Selain peningkatan keterampilan dalam sumber daya manusia, diperlukan juga revitalisasi dalam sistem manajerial dan kemudahan akses teknologi pada UMKM.

Kata Kunci: Daya Saing; Geographic Information System; UMKM

\section{PENDAHULUAN}

Pengembangan ekonomi kreatif di Indonesia sangat tepat dilakukan melalui model Usaha Mikro, Kecil dan Menengah (UMKM) (Ananda \& Susilowati, 2017). Keberadaan UMKM memegang peran penting dan strategis dalam pembangunan ekonomi nasional (Fadhila \& Cahyono, 2017). Selain berperan dalam pertumbuhan ekonomi dan penyerapan tenaga kerja, UMKM juga berperan dalam mendistribusikan hasil-hasil pembangunan (Bank Indonesia, 2015).

Kontribusi

\section{UMKM}

dalam

pembangunan ekonomi tidak dapat dipandang sebelah mata. UMKM dapat memberikan pelayanan ekonomi secara luas kepada masyarakat, proses pemerataan dan peningkatan pendapatan, mendorong pertumbuhan ekonomi, serta mewujudkan stabilitas nasional. Masalah-masalah ekonomi dan sosial seperti tingginya tingkat kemiskinan, ketimpangan distribusi pendapatan, proses pembangunan yang tidak merata antara daerah perkotaan dan perdesaan, serta masalah urbanisasi diharapkan dapat diselesaikan melalui pengembangan UMKM (Bank Indonesia, 2015).

Perkembangan dan peningkatan kelas usaha pada UMKM bukan hal yang mudah 
untuk dilakukan. Berbagai masalah pengembangan UMKM menjadi kendala dalam peningkatan daya saing. Faktor yang mempengaruhi daya saing UMKM dapat dibedakan menjadi faktor internal dan faktor eksternal. Faktor internal mencakup aspekaspek yang menentukan daya saing perusahaan yang bersifat internal perusahaan seperti produktivitas dan inovasi. Sementara faktor eksternal mencakup kemudahan berusaha di Indonesia (ease of doing business), akses finansial dan permodalan, akses pasar, infrastruktur, serta kondisi makroekonomi secara umum (LPPI \& Bank Indonesia, 2015).

Salah satu daerah yang memiliki potensi UMKM yang tinggi yaitu Kota Tasikmalaya. Kota Tasikmalaya merupakan salah satu daerah di wilayah Priangan Timur yang memiliki industri ekonomi kreatif yang berkembang pesat. Namun, pengembangan UMKM di Kota Tasikmalaya dihadapkan pada kendala di berbagai aspek seperti sumber daya manusia, teknologi, manajerial, kelembagaan, promosi, dan permodalan. Hal ini menyebabkan daya saing UMKM masih tergolong rendah baik secara nasional maupun secara global (Dinas Koperasi dan UMKM Provinsi Jawa Barat, 2016).

Salah satu strategi peningkatan daya saing UMKM dapat dilakukan dengan pengembangan klaster (klasterisasi) pada UMKM yang sudah ada. Klasterisasi digunakan agar dapat menghubungkan UMKM yang satu dengan UMKM yang lain sehingga dapat mengoptimalkan klaster UMKM pada sektor tertentu. Dengan klasterisasi, diharapkan dapat mendorong terciptanya inovasi serta sinergitas diantara pelaku-pelaku terkait (Bappenas, 2015).

Tujuan penelitian yaitu untuk mengetahui kondisi kluster UMKM Kota Tasikmalaya, menganalisa daya saing masing-masing kluster UMKM, serta memberikan rekomendasi strategi bagi pengembangan klaster UMKM. Klaster dapat didefinisikan sebagai adalah konsentrasi geografis antara perusahaan- perusahaan yang saling terkait dan bekerja sama, diantaranya pemasok barang, penyedia jasa, industri yang terkait, serta beberapa institusi (Bappenas, 2005). Hubungan antar perusahaan dalam klaster dapat bersifat horizontal atau vertikal. Bersifat horizontal melalui mekanisme produk jasa komplementer, penggunaan berbagai input khusus, teknologi atau institusi. Sedangkan sifat kerjasama vertikalnya antara lain dapat dilakukan melalui rantai pembelian dan penjualan (Sunaryanto, 2010).

Pendekatan klaster dinilai strategis karena bersifat terintegrasi, meningkatkan daya tawar dan lebih menguntungkan, tidak hanya efisiensi biaya tetapi juga bagi pengembangan ekonomi wilayah. Pendekatan klaster juga mampu menstimulasi inovasi melalui pertukaran pengalaman dan pengetahuan antar pelaku dalam hubungan hulu-hilir serta mampu memberikan kerangka untuk menghadapi tantangan globalisasi (Bappenas, 2005).

Klasterisasi dapat dilakukan dengan analisis spasial yang dapat digunakan untuk mengeksplorasi karakteristik spasial dan atribut tertentu. Penggunaan teknologi informasi berupa Geographic Information System (GIS) merupakan hal yang baru dalam pembentukan klaster UMKM. Kemampuannya untuk menangkap, menyimpan, menganalisa, memodelkan, dan memetakan area yang luas dengan data spasial yang besar menjadikan GIS dapat meningkatkan efektifitas dan efisiensi (Escobar et al, 2012).

GIS adalah sistem yang dirancang untuk menangkap, menyimpan, memanipulasi, menganalisa, dan mengatur semua tipe data yang bersifat geografis (Huisman dan Rolf, 2009). Kemampuannya untuk menangkap, menyimpan, menganalisa, memodelkan, dan memetakan area yang luas dengan data spasial yang besar menjadikan GIS aplikasi yang luar biasa (Hunter \& Bishop, 2012). 
GIS terdiri dari sekumpulan user, aplikasi, data, software dan hardware yang saling bekerja sama dalam menyimpan, mengubah, menghapus dan menampilkan data dalam suatu informasi berbasis geografis. Data yang diolah pada GIS berupa data geo spasial, yakni data spasial dan data non spasial (Harmon dan Anderson, 2003). Data yang berhubungan dengan kondisi geografi, seperti sungai, wilayah administrasi, gedung, jalan raya dan lain sebagainya adalah wujud data spasial. Sedangkan data yang berupa teks atau angka, yang biasanya disebut dengan atribut adalah wujud data nonspasial (Alfiana dan Susanti, 2018).

Analisis klaster dalam penelitian ini diharapkan dapat menyajikan informasi mengenai lokasi, atribut, serta industri kreatif dengan berbasis peta. Peta yang dihasilkan dapat dijadikan sebagai alat yang tepat untuk membuat rekomendasi pengembangan UMKM berbasis kearifan lokal. Berdasarkan uraian tersebut maka penelitian terkait strategi pengembangan klaster UMKM dengan menggunakan GIS di Kota Tasikmalaya dinilai penting untuk dilakukan dalam rangka pengembangan perekonomian daerah.

\section{METODE}

Penelitian ini dilaksanakan dengan metode deskriptif kuantitatif melalui dua tahap. Tahap pertama yaitu penentuan bobot prioritas enam variabel daya saing UMKM yang terdiri dari sumber daya manusia, teknologi, manajerial, kelembagaan, promosi, dan permodalan. Pembobotan didapatkan melalui wawancara secara mendalam (indepth interview) kepada expert yang telah ditentukan. Metode wawancara yaitu dengan menggunakan kuesioner perbandingan berpasangan dengan skala Saaty 1-9. Nilai-nilai relatif kemudian diolah untuk menentukan peringkat relatif dari seluruh variabel yang diamati.
Tabel 1. Skala Penilaian Kriteria

Perbandingan berpasangan Saaty

\begin{tabular}{cc}
\hline Nilai & Keterangan \\
\hline 1 & sama penting \\
3 & lebih penting \\
5 & jelas lebih penting \\
7 & sangat jelas lebih penting \\
9 & mutlak lebih penting \\
& nilai diantara dua elemen yang \\
$2,4,6,8$ & berdekatan \\
\hline
\end{tabular}

Sumber : Saaty, 2006

Penentuan bobot dilakukan membandingkan setiap variabel dengan matriks berpasangan. Matriks hasil Perbandingan berpasangan direpresentasikan kedalam bentuk vertikal dan horizontal berbentuk matriks yang bersifat stochatic disebut sebagai supermatriks. Tahapan pembentukan supermatriks yaitu: Supermatriks tanpa bobot (Unweighted Super Matrix), dupermatriks asli yang diperoleh dari eigenvector-eigenvector kolom dieroleh dari matriks perbandingan berpasangan. Supermatriks terbobot (weighted Super Matrix), diperoleh dengan mengalikan semua elemen didalam komponen dari Unweighted Super Matrix dengan bobot cluster yang sesuai sehingga setiap kolom pada weighted Super Matrix memiliki jumlah 1. Supermatriks batas (Limitting Super Matrix), diperoleh dari mengalikan weighted Super Matrix dengan dirinya sendiri sampai beberapa kali. Ketika bobot pada setiap kolom memiliki nilai yang sama, maka limit matrix telah stabil dan proses perkalian matriks dihentikan

\begin{tabular}{l|llll}
$c$ & $A_{1}$ & $A_{2}$ & 000 & $A_{n}$ \\
\hline$A_{1}$ & $A_{11}$ & $A_{12}$ & 000 & $A_{1 n}$ \\
$A_{2}$ & $A_{21}$ & $A_{22}$ & 000 & $A_{2 n}$ \\
000 & 0 & 0 & 000 & $A_{3 n}$ \\
$A_{n}$ & $A_{n 3}$ & $A_{n 2}$ & 000 & $A_{n n}$
\end{tabular}




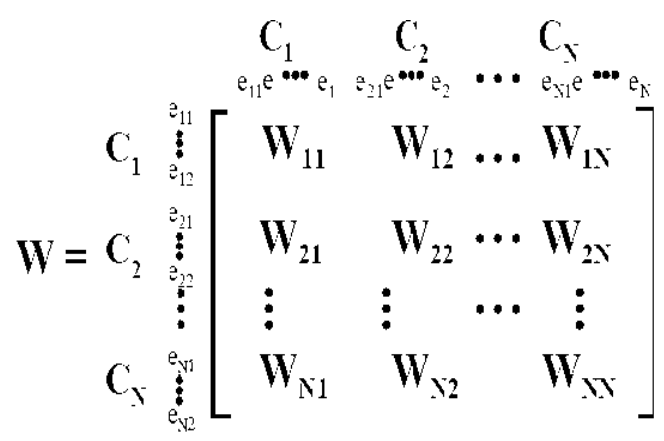

Sumber : Marimin \& Maghfiroh, 2010

Gambar 1. Pembentukan Supermatiks

Dalam perhitungan bobot di atas, nilai konsistensi juga menjadi perhatian. Consistency Ratio (CR) merupakan parameter yang digunakan untuk memeriksa perbandingan berpasangan telah dilakukan dengan konsekuen atau tidak. Formula yang digunakan yaitu:

$$
\begin{aligned}
\mathrm{CI} & =(\Lambda \text { rata-rata }-\mathrm{n}) /(\mathrm{n}-1) \\
\mathrm{CR} & =\mathrm{CI} / \mathrm{RI}
\end{aligned}
$$

Tabel 2. Nilai Random Indeks

\begin{tabular}{cccccc}
$\mathrm{N}$ & 1 & 2 & 3 & 4 & 5 \\
\hline $\mathrm{RI}$ & 0.00 & 0.00 & 0.58 & 0.90 & 1.12 \\
\hline $\mathrm{N}$ & 6 & 7 & 8 & 9 & 10 \\
\hline $\mathrm{RI}$ & 1.24 & 1.32 & 1.41 & 1.45 & 1.49
\end{tabular}

Sumber : Marimin \& Maghfiroh, 2010

Dimana $\mathrm{CI}=$ Consistency Index, $\Lambda$ $=$ Consistency Vector, $n=$ Jumlah alternatif, $\mathrm{CR}=$ Consistensy Ratio

Tahap kedua penelitian yaitu melakukan observasi dan wawancara dengan menggunakan kuesioner kepada UMKM yang telah ditentukan. Pada saat observasi dilakukan penentuan titik UMKM dengan menggunakan Global Positioning System (GPS). Wawancara dilakukan dengan menggunakan kuesioner terstruktur yang sudah ditentukan.

Data hasil observasi dan wawancara pada tahap ini kemudian diolah dengan menggunakan software Arc GIS 10.5. Eksplorasi karakteristik data daya saing dilakukan dengan menggunakan teknik overlay dari setiap variabel daya saing. Operasi overlay, seperti Intersect, Identitas, dan Union dapat menghasilkan geometri yang berbeda dalam output, tetapi kepentingan utama overlay adalah bahwa atribut digabungkan dari input. Overlay tidak hanya sebuah operasi yang menggabungkan atau split fitur geometri berdasarkan hubungan spasial fitur, tetapi kekuatan sebenarnya dari overlay adalah kenyataan bahwa atribut digabungkan saat fitur berpotongan dan dipertahankan dalam tabel atribut output. Proses overlay menghasilkan satu peta analisis yang berasal dari enam variabel. Peta analisis ini berisi tingkat daya saing setiap UMKM yang terlibat dalam penelitian.

\section{HASIL DAN PEMBAHASAN}

Kota Tasikmalaya terdiri dari sepuluh kecamatan antara lain Kecamatan Tawang, Bungursari, Tamansari, Cibeureum, Cihideung, Indihiang, Cipedes, Kawalu, Mangkubumi, dan Purbaratu. Setiap kecamatan di Kota Tasikmalaya memiliki karakteristik tersendiri dalam menghasilkan produk kerajinan. Melalui produk-produk tersebut ekonomi tumbuh dalam bentuk UMKM yang memiliki ciri khas tersendiri. UMKM tersebut sangat berperan dalam kesejahteraan masyarakat.

Produk yang dihasilkan Kota Tasikmalaya dapat dikategorikan sebagai produk industri kreatif. Peraturan Presiden Nomor 142 Tahun 2018 tentang Pengembangan Ekonomi Kreatif Indonesia Tahun 2025 memuat 16 elemen yang tergolong dalam industri kreatif antara lain : (1). Aplikasi dan Game Developer, (2). Arsitektur, (3). Desain Interior, (4). Desain Komunikasi Visual, (5). Desain Produk, (6). Fashion, (7). Film, Animasi, dan Video, (8). Fotografi, (9). Kerajinan, (10). Kuliner, (11). Musik, (12). Penerbitan, (13). Periklanan, (14). Seni pertunjukkan, (15). Seni Rupa, dan (16). Televisi dan Radio. 
Berdasarkan pengelompokan tersebut, Kota Tasikmalaya menghasilkan paling sedikit tiga kelompok industri kreatif sesuai peraturan di atas. Kerajinan tangan merupakan produk yang sangat populer yang dihasilkan dari Kota Tasikmalaya. Kecamatan Tamansari menghasilkan kelom geulis, Kecamatan Mangkubumi menghasilkan alas kaki, Kecamatan Cipedes menghasilkan batik, Kecamatan Indihiang dan Cihideung menghasilkan payung geulis, Kecamatan Cibeureum menghasilkan jaket, Kecamatan Kawalu menghasilkan bordir, Kecamatan Purbaratu menghasilkan mendong, Kecamatan Tawang menghasilkan produk kayu, dan Kecamatan Bungursari menghasilkan kerajinan kulit.

Produk di masing-masing kecamatan dianalisis dengan menggunakan analisis enam variabel penentu daya saing UMKM. Hasil analisis perbandingan berpasangan menunjukkan bahwa menurut pakar, faktor terbesar yang berpengaruh terhadap daya saing UMKM Kota Tasikmalaya yaitu sumber daya manusia dengan bobot prioritas $42 \%$. Diikuti oleh faktor manajerial (22\%), teknologi (14\%), promosi (11\%), kelembagaan $(6 \%)$, dan permodalan $(5 \%)$. Perbedaan prioritas bobot keenam faktor tersebut dapat dilihat pada Gambar 2.

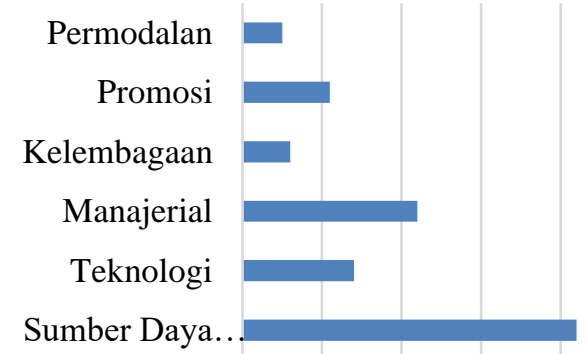

$\begin{array}{llllll}0,00 & 0,10 & 0,20 & 0,30 & 0,40 & 0,50\end{array}$

Gambar 2. Bobot Prioritas Penentu Daya Saing UMKM Kota Tasikmalaya

Hasil analisis perbandingan berpasangan menunjukkan nilai Consistency Ratio sebesar $1.8 \%$ (kurang dari 10\%). Nilai $1.8 \%$ pada penelitian menunjukkan bahwa pendapat pakar konsisten sehingga dapat diterima dan dijadikan dasar pertimbangan dalam menganalisis daya saing UMKM Kota Tasikmalaya. Konsistensi rasio yang tinggi pada penelitian menunjukkan bahwa pakar memiliki tingkat pemahaman yang tinggi dalam melakukan analisis terhadap UMKM (Marimin dan Maghfiroh, 2010). Peta daya saing UMKM Kota Tasikmalaya secara umum digambarkan pada Gambar 3.

Gambar 3 menunjukkan tingkat daya saing UMKM di setiap kecamatan yang ada di Kota Tasikmalaya. Pada umumnya UMKM masih memiliki tingkat daya saing yang rendah. Pengembangan UMKM produk kerajinan ini menjadi penting dalam mendukung potensi ekonomi kreatif Indonesia. Namun, pengembangan kerajinan di Kota Tasikmalaya mengalami kendala. Daya saing produk UMKM Kota Tasikmalaya dinilai masih rendah, sehingga kurang dapat bersaing di pasaran. Beberapa literatur studi menyatakan bahwa kemampuan UMKM bersaing di era global tergantung pada beberapa variable karakteristik (Bank Indonesia, 2015). Nicolescu (2009) membagi variabel tersebut menjadi variabel internal dan eksternal. Faktor internal yaitu faktor yang berasal dari dalam pengusaha UMKM itu sendiri, sedangkan faktor eksternal yaitu faktor yang berasal dari luar seperti budaya nasional, sistem ekonomi, dan daya beli masyarakat.

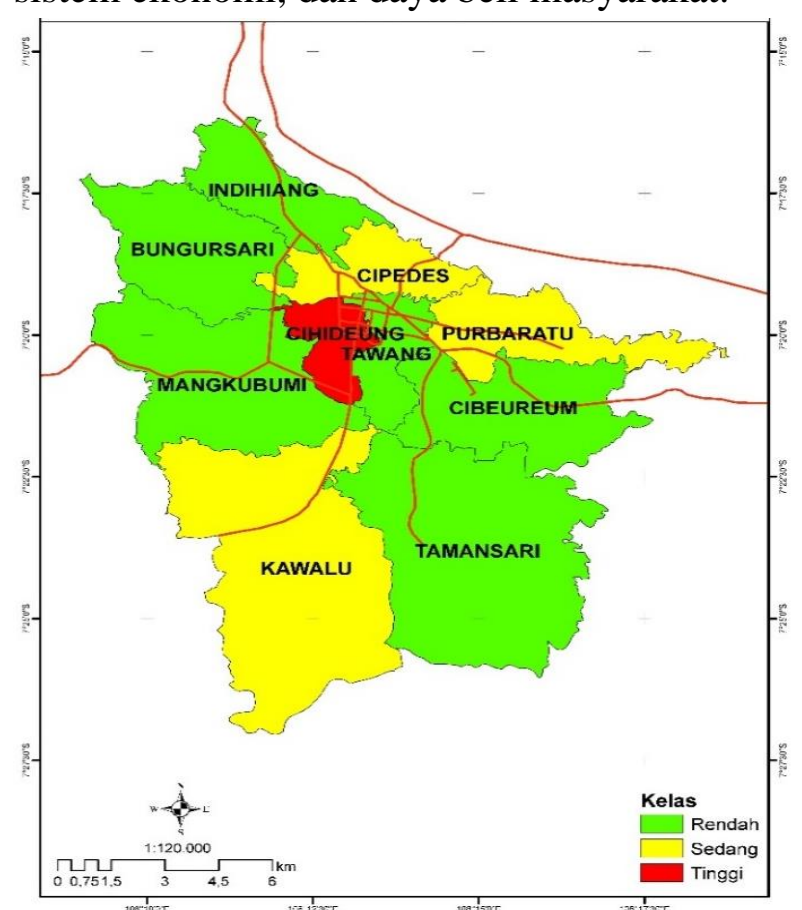

Gambar 3. Peta Daya Saing UMKM Kota Tasikmalaya 
Berbagai permasalahan terkait sumber daya manusia, manajerial, teknologi, promosi, kelembagaan, dan permodalan menjadi isu yang harus diperhatikan. Hal ini sesuai dengan pernyataan Darwanto (2013) yang menyatakan bahwa keunggulan bersaing UMKM tidak hanya ditekankan pada aspek sumber daya manusia, tetapi juga pada aspek lain seperti penguatan kelembagaan UMKM itu sendiri.

Prioritas utama dalam peningkatan daya saing UMKM Kota Tasikmalaya yaitu sumber daya manusia dengan bobot $42 \%$. Sumber daya manusia dalam konteks bisnis atau usaha adalah orang yang bekerja dalam suatu organisasi. Sumber daya manusia menjadi aset paling berharga yang harus dijaga demi kelangsungan usaha tersebut (Taufiqurrahman, 2009).

UMKM merupakan kegiatan usaha yang mampu memperluas lapangan kerja dan memberikan layanan ekonomi kepada masyarakat. Pentingnya peran UMKM dalam perekonomian justru tidak sejalan dengan pengelolaan sumber daya manusianya. Budaya dan struktur kerja informal serta tidak adanya rencana karir yang jelas membuat UMKM kesulitan dalam meningkatkan kualitas sumber daya manusia (Bank Indonesia, 2015). Kualitas sumber daya manusia pada UMKM dinilai masih rendah sehingga pengelolaannya sangat penting untuk dilakukan. Pengelolaan sumber daya manusia dilakukan agar kinerja UMKM menjadi optimal.

Pengelolaan sumber daya manusia UMKM perlu dilakukan tidak hanya kepada pemilik UMKM, tetapi juga dilakukan kepada para pekerjanya. Peningkatan kualitas sumber daya manusia terutama sebagai upaya peningkatan kompetensi di bidangnya. Kompetensi sangat berkaitan erat dengan kinerja, baik secara individu maupun dalam organisasi. Mathis \& Jackson (2001) menyatakan bahwa kinerja adalah fungsi dari kemampuan, usaha dan dukungan.
Produk UMKM Kota Tasikmalaya yang berbasis kerajinan tangan menjadikan keahlian sumber daya manusia menjadi sangat penting untuk ditingkatkan. Keahlian tidak hanya ditekankan pada pekerja dalam proses produksi tetapi juga pada pengusaha terkait dengan wawasan bisnis. Wawasan pengusaha atau pemilik UMKM yang luas sangat penting bagi terciptanya inovasi.

Keahlian baik pekerja maupun pengusaha UMKM berbanding lurus dengan tingkat pendidikan. UMKM dengan daya saing tinggi cenderung memiliki pekerja dan pengusaha dengan tingkat pendidikan tinggi (Tambunan, 2015). Pemilik UMKM dengan tingkat pendidikan yang tinggi terbukti lebih memahami usaha yang dijalankan. Profil tingkat pendidikan pekerja di Kota Tasikmalaya masih sangat rendah. Peta daya saing sumber daya manusia UMKM Kota Tasikmalaya ditunjukkan pada Gambar 4.

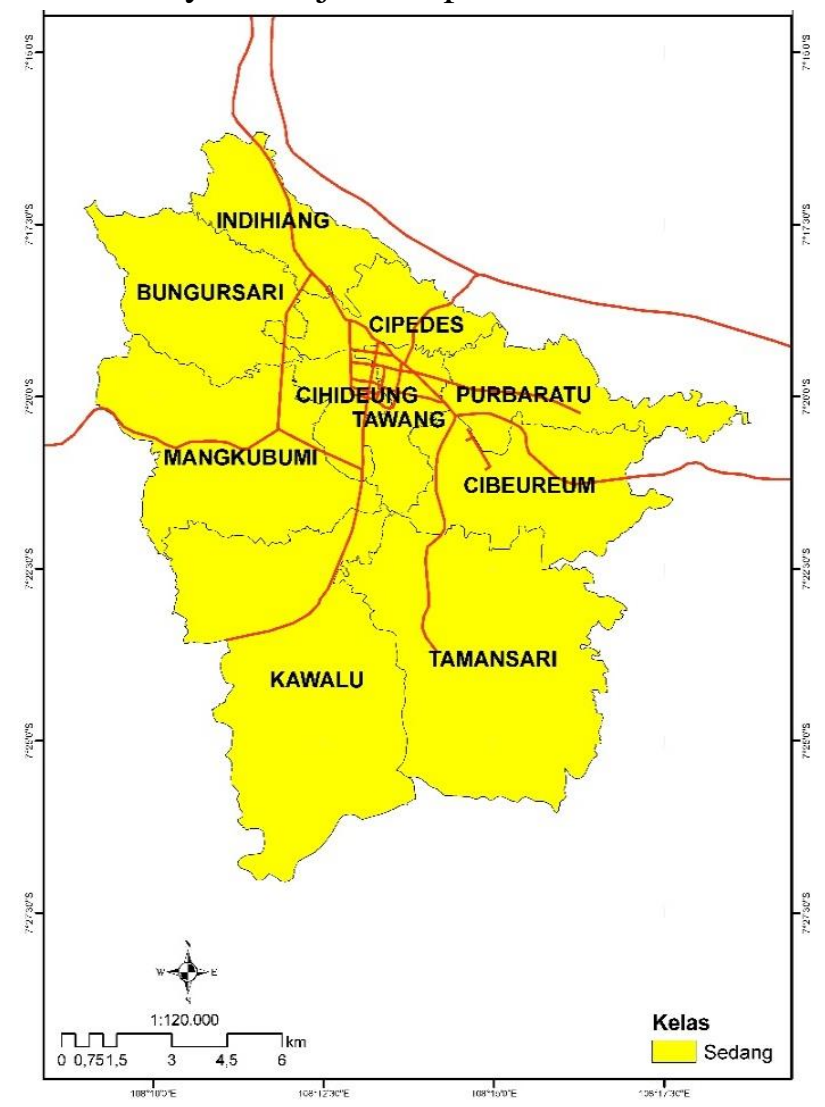

Gambar 4. Peta Daya Saing Sumber Daya Manusia UMKM Kota Tasikmalaya

Berdasarkan hasil wawancara dengan UMKM, rata-rata pekerja didominasi 
dengan tingkat pendidikan Sekolah Dasar sampai Sekolah Menengah Pertama. Keterampilan pekerja rata-rata UMKM Kota Tasikmalaya tergolong sedang, dimana pekerja sudah memiliki bakat dalam membuat kerajinan tangan yang diturunkan secara turun temurun dalam keluarga.

Keterampilan yang tergolong sedang tidak diimbangi dengan dukungan pelatihan yang memadai. Hasil survey menunjukkan bahwa pelatihan pengembangan UMKM masih sangat jarang diikuti oleh pelaku UMKM di Kota Tasikmalaya. Kurangnya pelatihan dan pendampingan menyebabkan rendahnya inovasi, sehingga hampir semua UMKM Kota Tasikmalaya kalah bersaing dengan produk lainnya termasuk produk impor.

Rendahnya kualitas sumber daya manusia pada UMKM Kota Tasikmalaya dapat dilihat dari beberapa karakteristik. Pertama, kurangnya pengetahuan terhadap teknologi terbaru sehingga produk yang dihasilkan kurang berinovasi. Kedua, kemampuan membaca kebutuhan pasar belum tajam sehingga belum mampu menangkap dengan cermat kebutuhan pasar. Hal ini terutama dilihat dari sisi pemilik usaha. Ketiga, belum adanya rencana strategis jangka panjang karena pemilik usaha sering terlibat persoalan teknis. Pada umumnya UMKM belum memiliki tujuan jangka panjang yang menjadi pedoman pengembangan bisnisnya. Keempat, rendahnya motivasi secara individu dalam menjalankan bisnis berpengaruh terhadap kemampuan pelaku UMKM dalam menghadapi tantangan dan perubahan zaman. Keempat karakteristik tersebut sesuai dengan pendapat LPPI dan Bank Indonesia (2015) dimana kendala tersebut menjadi gambaran umum profil UMKM di Indonesia.

Peningkatan kualitas sumber daya manusia UMKM harus disertai dengan evaluasi dan kesinambungan program. Program ini tidak hanya melibatkan UMKM, tetapi juga melibatkan stakeholder lain seperti pemerintah dan swasta. Pelatihan mengenai entrepreneurship, pencatatan laporan keuangan, peningkatan komunikasi dan pemasaran, dan pelatihan digital menjadi prioritas program yang harus dilakukan.

Prioritas kedua dalam upaya peningkatan daya saing UMKM Kota Tasikmalaya yaitu manajerial dengan bobot $22 \%$. Dari segi manajerial, indikator yang diamati pada penelitian ini yaitu proses organisasi dan manajemen dalam UMKM. Proses ini meliputi kegiatan perencanaan, pengorganisasian, pelaksanaan, dan kontroling atau pengawasan. Kegiatan manajemen dalam UMKM meliputi pengorganisasian tenaga kerja, pengadaan bahan baku, pemasaran, administrasi dan pembukuan. Kondisi daya saing UMKM Kota Tasikmalaya dilihat dari sisi manajerial ditunjukkan pada Gambar 5.

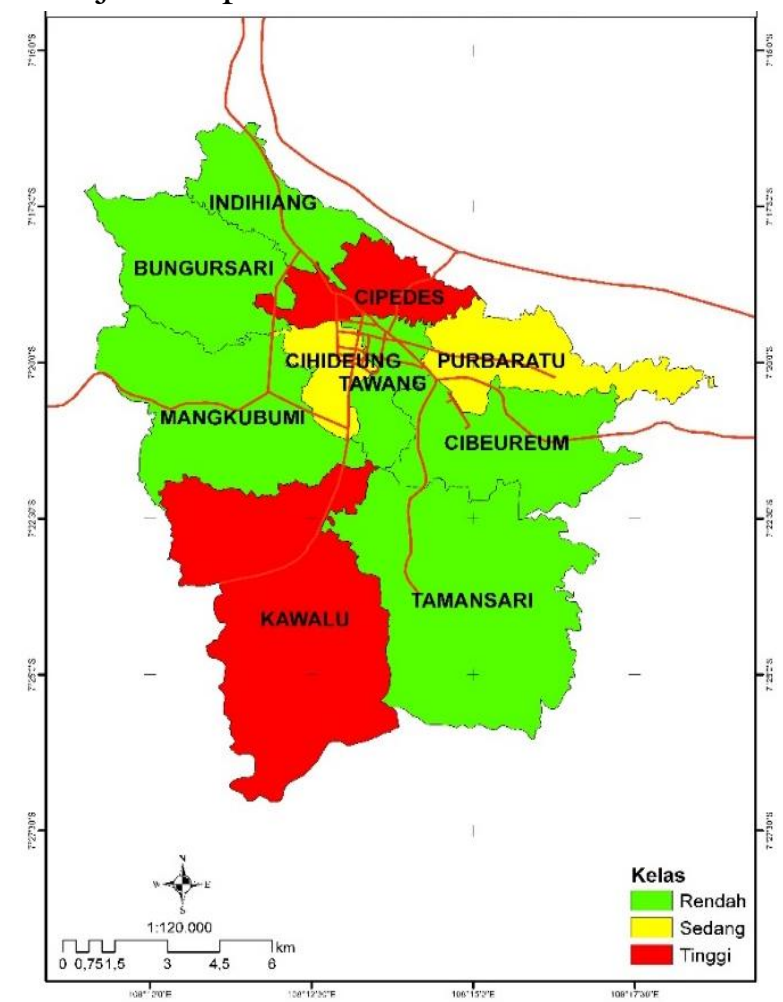

Gambar 5. Peta Daya Saing Manajerial UMKM Kota Tasikmalaya

Gambar di atas menunjukkan bahwa pada umumnya UMKM Kota Tasikmalaya belum menerapkan sistem organisasi dan manajemen secara profesional. Manajemen usaha keluarga yang dijalankan secara turun temurun masih bersifat manual dan tradisional. Belum adanya pembagian deskripsi yang jelas diantara pekerja, proses 
administrasi masih belum tertata dengan rapi, dan proses pembukuan masih dilakukan secara sederhana.

Pengusaha UMKM juga belum memiliki sistem manajemen keuangan yang memadai. Pemisahan antara uang operasional rumah tangga dan usaha belum dilakukan sehingga masih tercampur. Kondisi tersebut terutama ditunjukkan pada UMKM yang terdapat di Kecamatan Indihiang, Bungusari, Mangkubumi, Tamansari, Tawang, dan Cibeureum. Sebaliknya, Kecamatan Kawalu dan Cipedes dinilai memiliki pengorganisasian manajemen yang cukup baik. Kawalu dengan produk bordir dan Cipedes dengan produk batik menunjukkan tingkat daya saing manajerial yang lebih tinggi. Proses perencanaan sampai pengawasan di kedua kecamatan tersebut dilakukan secara profesional. Hal ini terbukti dengan produk yang dihasilkan memiliki kualitas premium dan dapat memasok swalayan modern di kota besar seperti Jakarta.

Proses manajerial yang sederhana erat kaitannya dengan kemampuan sumber daya manusia yang belum memadai (LPPI dan Bank Indonesia, 2015). Sistem organisasi dan manajemen yang baik dalam sebuah UMKM merupakan faktor penting untuk menciptakan inovasi (Darwanto, 2013). Usaha UMKM Kota Tasikmlaya pada umumnya dikelola oleh keluarga dan sangat tergantung pada satu orang tertentu. Karakteristik ini mengancam keberlanjutan usaha UMKM tersebut (LPPI dan Bank Indonesia, 2015). Keberlanjutan usaha yang tergantung pada satu figur bukan sistem membuat UMKM tidak dapat bertahan. Hal ini terjadi pada UMKM Payung Geulis di Kecamatan Indihiang yang usahanya menurun ketika orang tertentu tidak ada.

Untuk mengatasi hal tersebut, pengusaha atau pemilik UMKM harus mampu menyiapkan tenaga kerja terlatih, modal yang cukup, teknologi yang sesuai, serta membangun jaringan kerja sama dengan pihak lain. Untuk itu organisasi dan manajemen dalam UMKM tidak bisa diterapkan dengan sederhana seperti yang ada saat ini. Proses perencanaan sampai pengawasan perlu dilakukan secara profesional sehingga tidak menghambat jalannya usaha.

Prioritas ketiga dalam peningkatan daya saing UMKM Kota Tasikmalaya yaitu teknologi dengan bobot 14\%. Teknologi digunakan baik dalam proses produksi ataupun dalam proses pemasaran. Pengembangan teknologi merupakan salah satu sumber penting dalam menciptakan inovasi. Jika teknologi yang digunakan oleh UMKM tertinggal, maka produk yang dihasilkan juga akan tertinggal.

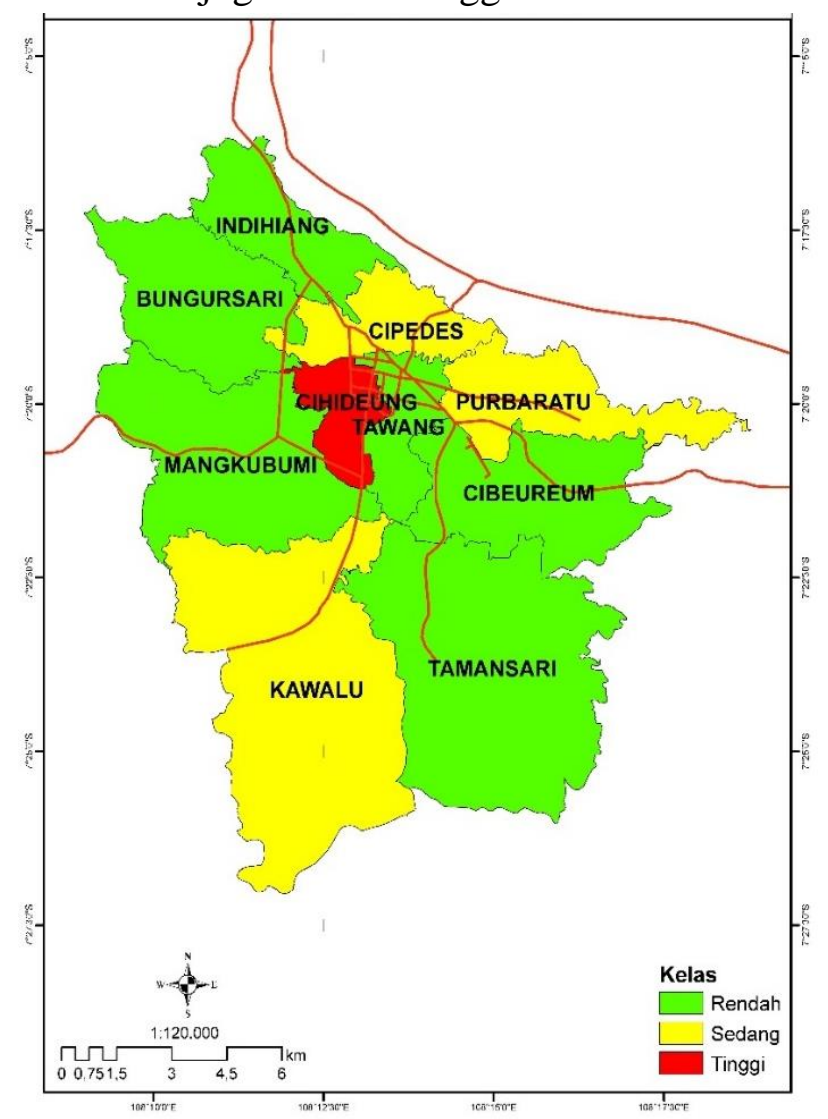

Gambar 6. Peta Daya Saing Teknologi UMKM Kota Tasikmalaya

Permasalahan UMKM Kota Tasikmalaya yaitu karakteristik UMKM yang pada umumnya belum memiliki kemampuan teknologi yang memadai. Produk kerajinan yang biasanya berbentuk handmade belum memiliki standar kualitas. Selain karena karakteristik produk yang 
berupa handmade, akses UMKM terhadap teknologi juga masih terbatas. Hal ini sesuai dengan pernyataan LPPI dan Bank Indonesia (2015) yang menyatakan bahwa pengetahuan UMKM mengenai teknologi produksi terbaru dan cara menjalankan quality control terhadap produk masih rendah. Peta daya saing teknologi UMKM Kota Tasikmalaya ditunjukkan pada Gambar 6.

Akses teknologi yang rendah disebabkan karena pasar dikuasai oleh perusahaan atau kelompok tertentu. Peralatan produksi merupakan investasi yang harganya tidak murah. Untuk dapat mengakses teknologi terkini, UMKM harus memiliki modal yang kuat. Mahalnya teknologi produksi tidak dapat dijangkau oleh pelaku UMKM karena pada umumnya UMKM mengalami kendala dari segi finansial (Hadiwidjaja dan Hartati, 2015).

Teknologi internet yang ada belum dapat digunakan secara optimal karena ratarata pelaku UMKM berusia tua. Kemauan dan kemampuan dalam menguasai teknologi pada UMKM sangat terbatas. Hal ini menyebabkan UMKM tidak dapat mengimbangi selera konsumen yang berubah dengan cepat. UMKM yang diamati belum memanfaatkan teknologi informasi seperti pembuatan web dan sosial media. UMKM Kota Tasikmalaya tidak dapat bersaing dengan perusahaan besar yang memiliki modal yang besar dalam mengakses teknologi. Perubahan selera konsumen akibat globalisasi menyebabkan pemilik UMKM harus dapat menyesuaikan dengan melakukan perputaran usaha yang sesuai dengan perkembangan zaman.

Skema bantuan selama ini lebih fokus pada pemberian kredit harus berubah pada bantuan teknis atau teknologi. Pemberian akses teknologi kepada UMKM dibutuhkan agar produk yang dihasilkan dapat bersaing dan diterima konsumen. Fokus peningkatan teknologi diarahkan pada proses produksi, manajemen, dan pemasaran. Dengan adanya bantuan teknologi pada ketiga aspek tersebut diharapkan dapat menjadi motor penggerak bagi terciptanya inovasi (Tambunan, 2015).
Prioritas keempat dalam peningkatan daya saing UMKM Kota Tasikmalaya yaitu promosi dengan bobot $11 \%$. Kemudahan akses pasar sangat mendukung peningkatan daya saing UMKM. Suatu produk yang kualitasnya bagus tidak akan berarti apa-apa jika tidak sampai ke tangan konsumen. Untuk dapat menyampaikan produknya sampai ke konsumen, maka UMKM harus aktif memperkenalkan diri melalui berbagai media promosi. Pelaku UMKM harus dapat menginformasikan keunggulan produk yang dimilikinya dan perbedaan dengan produk sejenis lainnya. Peta daya saing promosi UMKM Kota Tasikmalaya ditunjukkan pada Gambar 7.

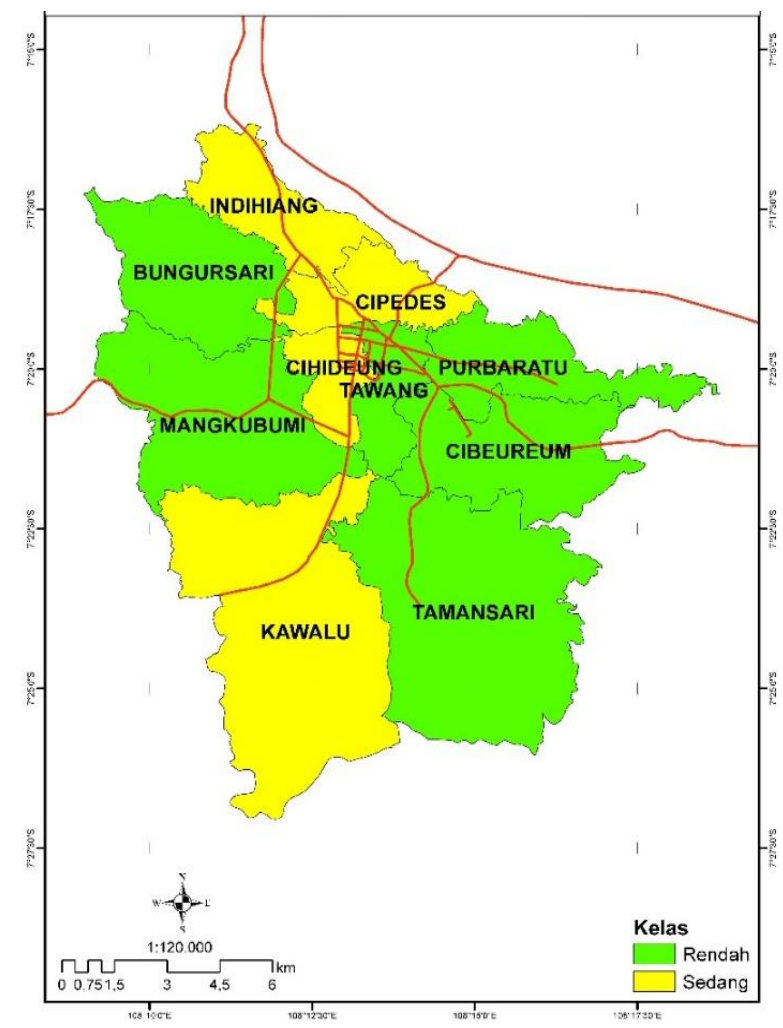

Gambar 7. Peta Daya Saing Promosi

UMKM Kota Tasikmalaya

Promosi produk UMKM Kota Tasikmalaya dinilai masih rendah. Hal ini dapat dilihat dari tingkat penguasaan pasar oleh produk yang dihasilkan. Produk alas kaki, kelom geulis, produk kayu, mendong, produk kulit, dan anyaman tidak begitu dikenal oleh masyarakat. Sedangkan untuk produk payung geulis bordir, dan batik dinilai lebih dikenal dihasilkan di Kota Tasikmalaya. Peta daya saing promosi 
UMKM Kota Tasikmalaya ditunjukkan pada Gambar 7.

Rata-rata UMKM yang diamati kurang memperhatikan pemasaran produknya. Mereka belum memiliki strategi pemasaran seperti harga yang berkompetisi, diskon untuk konsumen, maupun layanan purna jual. Kemajuan internet nyatanya belum dimanfaatkan secara optimal dalam mempromosikan produk yang dihasilkan. Padahal saat ini sudah banyak media promosi yang dapat digunakan seperti Facebook, Twitter, Instagram, Youtube, dan media pemasaran lainnya. Bahkan beberapa UMKM justru hanya mengandalkan pesanan dari pelanggan yang ada dan menjualnya ke pasar yang ada di Kota Tasikmalaya. Kesadaran untuk memperluas jangkauan pemasaran melalui e-commerce masih sangat rendah. Hal ini sesuai dengan pernyataan LPPI dan Bank Indonesia (2015) yang menyatakan bahwa pemasaran produk masih mengandalkan cara sederhana yaitu dengan mouth to mouth marketing. UMKM belum menjadikan media sosial atau jaringan internet sebagai alat pemasaran.

Rendahnya kegiatan promosi yang dilakukan berdampak pada pangsa pasar yang terbatas hanya di daerah saja. Jangkauan pemasaran hanya terbatas pada lingkup domestik yang dibatasi oleh daerah dan lingkungan pertemanan atau keluarga. Beberapa UMKM, seperti Payung Geulis enggan untuk menerima pesanan secara online karena produk tidak siap kirim. Tidak ada stok produk yang disimpan karena kurangnya modal. Produk hanya dibuat jika ada pesanan saja. Dalam kasus ini, produk yang dipesan secara online tidak dapat dilayani karena UMKM membutuhkan waktu cukup lama sampai dapat dikirim.

Sosialisasi manfaat penggunaan ecommerce diperlukan dengan didampingi oleh pemilik e-commerce dan pemerintah. Pelatihan khususnya dalam basic digital saat ini diharapkan dapat meningkatkan jangkauan pemasaran UMKM.
Prioritas kelima dalam peningkatan daya saing UMKM Kota Tasikmalaya yaitu kelembagaan dengan bobot 6\%. Pada umumnya UMKM mempunyai keterbatasan dalam membangun hubungan industri dan sosial, mobilitas sumber daya, akses terhadap informasi, dan pengembangan sumber daya (Broughton, 2011). Untuk itu, diperlukan suatu organisasi berupa kelembagaan UMKM. Kelembagaan merupakan wadah atau tempat yang diharapkan dapat bermanfaat bagi kelancaran proses produksi dan pemasaran. Bentuk kelembagaan yang berupa koperasi atau gabungan UMKM membuat kegiatan usaha UMKM menjadi lebih kuat dan terorganisir dengan baik. Peta daya saing kelembagaan UMKM Kota Tasikmalaya ditunjukkan pada Gambar 8.

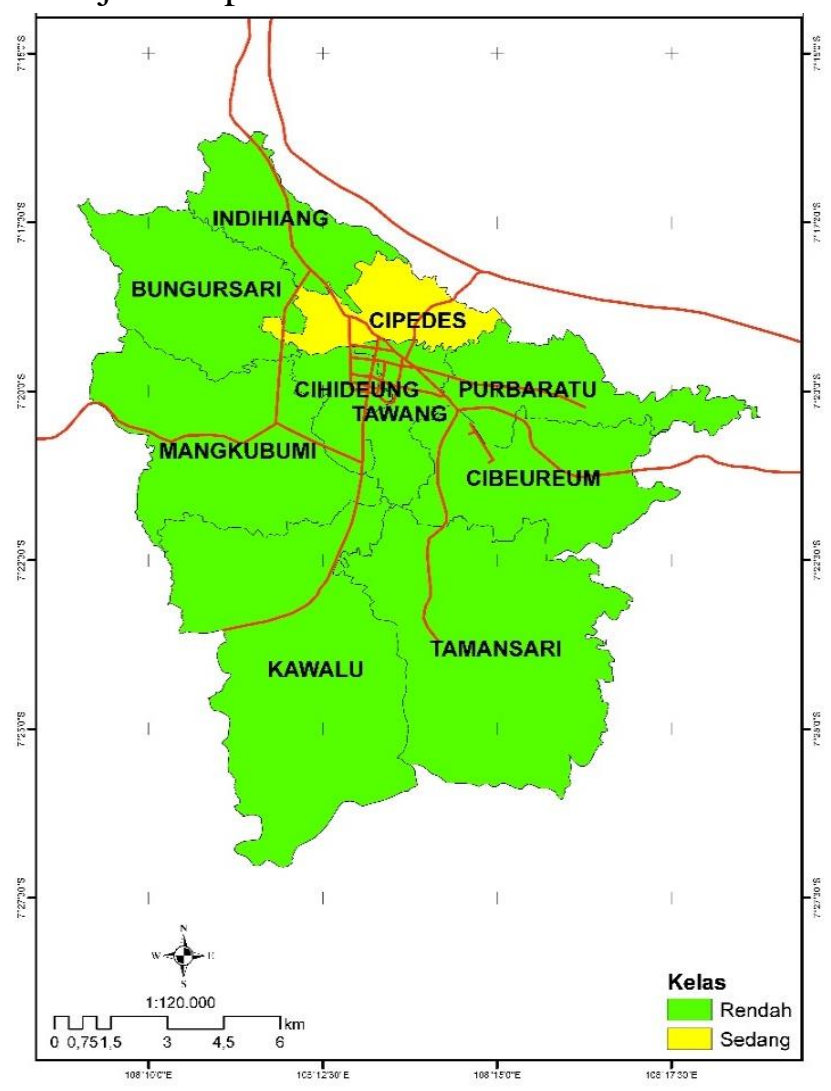

Gambar 8. Peta Daya Saing Kelembagaan UMKM Kota Tasikmalaya

Karakteristik UMKM Kota Tasikmalaya yaitu kualitas yang belum standar, desain produk terbatas, jenis produk terbatas, sulitnya penetapan harga, bahan 
baku tidak standar, dan kontinuitas produk yang belum terjamin. Karakteristik tersebut membuat peran koperasi atau gabungan UMKM menjadi penting. UMKM yang bergabung dalam kelompok memperoleh berbagai keuntungan yang tidak diperoleh jika beroperasi sendiri. Dengan membentuk kelompok, UMKM dapat bekerja sama dalam proses penyediaan bahan baku, penetapan harga, standarisasi produk, kuantitas produk, pemasaran, dan lain sebagainya.

Pada kenyataannya peran koperasi atau gabungan UMKM Kota Tasikmalaya belum berjalan optimal. Kerja sama antar UMKM belum terjalin dengan baik, padahal jika dilakukan kerja sama akan meningkatkan efisiensi dan efektivitas dalam menjalankan usaha. Menurut Darwanto (2013), kelembagaan yang kuat berperan bagi penciptaan kreativitas dan seni yang mampu meningkatkan daya saing UMKM dari beberapa negara. Rata-rata UMKM yang diamati menyatakan tidak memiliki keterkaitan dengan koperasi atau kelompok UMKM. Setiap UMKM menjalankan usaha sendiri-sendiri. Hal ini menyebabkan UMKM Kota Tasikmalaya tidak terintegrasi dengan baik. UMKM tidak memiliki kekuatan posisi yang dapat mengancam keberlanjutan usaha.

Dalam mengembangkan jaringan kerja sama antar UMKM perlu adanya bantuan dari pihak luar, dalam hal ini pemerintah. Adanya bimbingan teknis dan pemberian pemahaman kepada UMKM menjadi penting dilakukan agar UMKM memahami keuntungan dalam membangun jaringan kerja sama. Banyak diantara UMKM tidak mengerti adanya keuntungan jika mereka bekerja sama.

Prioritas keenam dalam peningkatan daya saing UMKM Kota Tasikmalaya yaitu permodalan dengan bobot 5\%. Sekitar 6070\% UMKM di Indonesia belum mendapat akses pembiayaan perbankan (Bank Indonesia, 2015). Hal ini disebabkan karena kendala administratif manajemen keuangan UMKM yang masih dikelola secara tradisional. Dukungan permodalan yang baik mendukung kelancaran usaha UMKM. Salah satu indikator permodalan UMKM dapat dilihat dari nilai investasi atau laju pertumbuhan rata-rata per tahun (Tambunan, 2015). Proses investasi terkait erat dengan penambahan kapasitas produksi baik itu dari penambahan tenaga kerja ataupun penambahan mesin-mesin produksi baru.

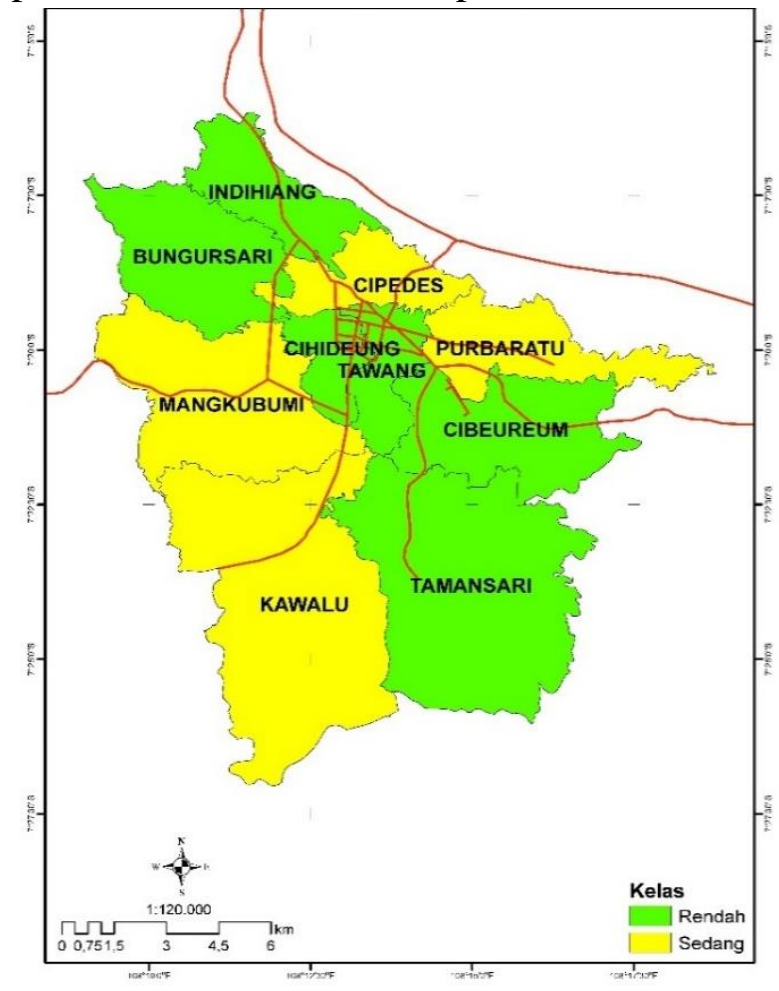

Gambar 9. Peta Daya Saing Permodalan UMKM Kota Tasikmalaya

Daya saing UMKM Kota Tasikmalaya pada aspek permodalan ditunjukkan pada Gambar 9. UMKM pada umumnya memiliki modal yang sangat terbatas dan berasal dari dana pribadi. Kurangnya permodalan dan terbatasanya akses pembiayaan menjadi permasalahan yang sering terjadi pada UMKM (Hadiwidjaja dan Hartati, 2013). Beberapa produk seperti kelom geulis di Kecamatan Tamansari, payung geulis di Kecamatan Indihiang, Produk Karet di Kecamatan Bungursari memiliki tingkat daya saing yang rendah. Sulitnya pendanaan untuk investasi menghambat keberlanjutan usaha. Bahkan ada produk kelom geulis di Kecamatan Tamansari yang sudah tidak diproduksi sejak empat tahun yang lalu.

Permasalahan permodalan di UMKM Kota Tasikmalaya harus diselesaikan secara 
simultan, baik dari sisi pemerintah maupun dari sisi pengusaha. Pemerintah dapat melakukan intervensi secara langsung maupun tidak langsung. Secara langsung, pemerintah dapat memberikan skim kredit khusus bagi UMKM dan mengadakan berbagai pelatihan terkait manajemen keuangan. Fasilitas pendanaan dengan tingkat suku bunga rendah, kemudahan proses, dan jangka waktu pengajuan kredit sangat diharapkan oleh pelaku UMKM. Secara tidak langsung, pemerintah dapat menetapkan kebijakan-kebijakan ekonomi makro yang berpengaruh terhadap iklim usaha (Bank Indonesia, 2015). Kebijakan ini antara lain kebijakan moneter, perbankan, ekspor impor ketenagakerjaan, dan lain sebagainya.

Dari sisi pengusaha permasalahan permodalan dapat diatasi dengan melakukan manajemen keuangan yang baik. Pada umumnya UMKM Kota Tasikmalaya belum memiliki sistem administrasi keuangan yang baik. Pengelolaan keuangan masih tercampur antara kepemilikan rumah tangga dan usaha. Hal ini menyebabkan pihak bank yang akan menyalurkan kredit kesulitan untuk mengetahui informasi lengkap mengenai keuangan UMKM.

Pola pikir UMKM yang berorientasi konsumtif mengurangi kepercayaan pihak perbankan dalam memberikan kredit. Perubahan pola pikir dari konsumtif menjadi investasi diperlukan agar UMKM yang dijalankan dapat berkembang. Perubahan pola pikir pada pelaku usaha UMKM dapat disiasati dengan memberikan pelatihan, bimbingan, dan pemahaman yang diadakan oleh pemerintah.

\section{KESIMPULAN}

Kota Tasikmalaya merupakan salah satu kota yang menghasilkan produk kerajinan tangan dengan keunikan tersendiri. Setiap kecamatan memiliki ciri khas produknya masing-masing. Kecamatan Tamansari menghasilkan kelom geulis, Kecamatan Mangkubumi menghasilkan alas kaki,
Kecamatan Cipedes menghasilkan batik, Kecamatan Indihiang dan Cihideung menghasilkan payung geulis, Kecamatan Cibeureum menghasilkan jaket, Kecamatan Kawalu menghasilkan bordir, Kecamatan Purbaratu menghasilkan mendong, Kecamatan Tawang menghasilkan produk kayu, dan Kecamatan Bungursari menghasilkan kerajinan kulit.

Hasil klasterisasi UMKM berdasarkan enam variabel daya saing menunjukkan bahwa UMKM Kota Tasikmalaya memiliki tingkat daya saing yang masih rendah. Strategi peningkatan daya saing UMKM di setiap kecamatan di Kota Tasikmalaya disesuaikan dengan pemetaan daya saingnya. Kegiatan pengembangan yang dilakukan dapat berupa pengembangan sumber daya manusia, peningkatan akses teknologi, pengembangan jaringan kerjasama baik secara internal maupun eksternal, peningkatan akses promosi, dan kemudahan akses permodalan.

Penelitian terkait daya saing UMKM di Kota Tasikmalaya perlu dilakukan secara berkesinambungan. Setelah dilakukan identifikasi terhadap daya saing, kajian terkait pengembangan dan keberlanjutan usaha UMKM menjadi penting dilakukan untuk mendukung pengembangan ekonomi kreatif di Indonesia.

\section{DAFTAR PUSTAKA}

Alifiana, M. A., \& Susanti, N. (2018). Analisis dan perancangan sistem informasi pemetaan UMKM berdasar potensi risiko berbasis GIS. SENDI_U, 289-294. Kudus: Universitas Muria Kudus.

Ananda, A. D., \& Susilowati, D. (2017). Pengembangan Usaha Mikro Kecil dan menengah (UMKM) berbasis industri kreatif di Kota Malang. Jurnal Ilmiah Ekonomi, 10, 120-142.

Bank Indonesia. (2015). Working Paper Daya Saing UMKM dalam Menghadapi. In Pemetaan dan Strategi 
Peningkatan Daya Saing UMKM dalam Menghadapi MEA 2015 dan Pasca MEA 2025 (No. L6, F16). Jakarta.

Bappenas. (2015). Panduan Pembangunan Klaster Industri untuk Pengembangan Ekonomi Daerah Berdaya Saing Tinggi (1st ed.). Retrieved from http://www.ghbook.ir/index.php?name Broughton, A. (2011). SMEs in the Crisis: Employment, Industrial Relations and Local Partnerships. Dublin: European Foundation for the Improvement of Living and Working Conditions. 2011.

Darwanto. (2013). Peningkatan Daya Saing UMKM Berbasis Inovasi Dan Kreativitas (Strategi Penguatan Property Right Terhadap Inovasi Dan Kreativitas). Jurnal Bisnis dan Ekonomi, 20, 142-149.

Dinas Koperasi dan UMKM Provinsi Jawa Barat, 2016. Bimbingan Teknis dan Pengembangan Industri Mendong dan Bambu. http://diskumkm.jabarprov.go.id/inde x.php/news/bintek-kab-tasikmalaya. Diakses 2 Maret 2019

Escobar, Hunter, Bishop, Zerger. (2012). GIS Theory. Department of Geomatics: The University of Melbourne.

Fadhila, A., \& Cahyono, A. B. (2017). Pembuatan webGIS untuk pemetaan Usaha Mikro Kecil Menengah (UMKM) di Kabupaten Blitar. Jurnal Teknik ITS, 6(2), 2-7. https://doi.org/10.12962/j23373539.v 6i2.23451

Hadiwidjaja, R.D \& Hartati, N. (2013). Kewirausahaan dalam Multi Perspektif. Jakarta: Universitas Terbuka.

Hunter, A. P. G., \& Bishop, A. P. I. (2012). Introduction to GIS. In Introduction to GIS (pp. 1-13). Retrieved from http://www.sli.unimelb.edu.au/gisweb/ $\% 0 \mathrm{ADr}$

Harmond \& Anderson. (2003). The Design and Implementation of Geograpics Information System. New Jersey: John Wiley \& Sons, Inc.
Huisman dan Rolf. (2009). Principle of Geographic Information System. Enchede: The International Institute for Geoinformation Science and Earth Observation.

LPPI \& Bank Indonesia. (2015). Profil Bisnis Usaha Mikro, Kecil Dan Menengah (UMKM). Jakarta: LPPI dan Bank Indonesia.

Marimin dan Maghfiroh, N. (2010). Aplikasi Teknik Pengambilan Keputusan dalam Manajemen Rantai Pasok. Bogor: IPB Press.

Mathis, R.L \& Jackson, J.H. (2001). Manajemen Sumber Daya Manusia. Jakarta: Salemba Empat.

Nicolescu, O (2009). Main features of SMEs organization system. Review of International Comperative Management, 10, 3-9.

Saaty, T.L. (2006). Decision Making With the Analithic Network Process. Pittsburgh: Springer.

Sunaryanto, L. (2010). Kajian Strategi Pengembangan Klaster Usaha Mikro, Kecil dan Menengah (UMKM) Berbasis Teknologi Informasi (TI). Salatiga: Universitas Kristen Satya Wacana.

Tambunan. (2015). Ukuran Daya Saing Koperasi dan UKM. Jakarta: Pusat Studi Industri dan UKM UniversitasTrisakti.

Taufiqurrahman. (2009). Mengenal Manajemen Sumber Daya Manusia. Jakarta: Fakultas Ilmu Sosial dan Ilmu Politik Universitas Prof. Dr. Moestopo Beragama. 